\title{
Korzenie pamięci O Mirabelce Cezarego Harasimowicza
}

\author{
The Roots of Memory \\ On Mirabelle by Cezary Harasimowicz
}

Abstract: The article attempts to interpret the novel Mirabelle in the light of hauntology, taken from Jacques Derrida's works, existing in the Polish literary studies first and foremost thanks to the works of Jakub Momro and Andrzej Marzec. Harasimowicz's novel recounts the history of Warsaw from the 1920s until the present-day period. The mirabelle plum tree growing on one of the backyards in Warsaw tells the story of the following generations of the city dwellers who fade away and fall into oblivion. The Holocaust, depicted in the beginning of the novel, does not, however, become the past. The recollection of the genocide is inscribed in contemporary Warsaw, in the city space and the consciousness of its inhabitants. The phantoms of the former dwellers of Nalewki, the Jewish district in Warsaw, visit their homes, little stores, and workshops, trying to end unfinished businesses and engaging with the representatives of the present-day citizens. The gesture of remembrance, which is the replanting and redeveloping a new mirabelle tree in the place of the damaged one, gives people hope for the restoration of balance and strengthens the bonds between the living and the dead.

Keywords: hauntology, memory, postmemory, Holocaust, Jewish culture

„Ja to mam szczęście!” - tak się zaczyna i tak też się kończy powieść Cezarego Harasimowicza Mirabelka. Przywołaną deklarację wygłasza na pół zdziczałe owocowe drzewko, które - pełniąc funkcję narratora - opowiada o losach mieszkańców kilku warszawskich kamienic, począwszy od czasów przedwojennych przez lata drugiej wojny światowej, stalinizm, wydarzenia 1968 roku oraz stan wojenny aż po współczesność. Kolejne pokolenia mirabelek przyglądają się przedwojennej kulturze polskich Żydów, są świadkami Zagłady, a w powojennej Polsce stają się strażniczkami pamięci i obserwatorkami szczególnego powiązania przeszłości z teraźniejszością. Pod gałęziami drzew obsypanych złotymi śliweczkami, w cieniu historycznych przemian, bawią się małe dziewczynki: Dorka - mieszkanka przedwojennych żydowskich Nalewek, Dorotka - która po 
wojnie wraz z rodzicami wprowadza się do nowego domu zbudowanego na $\mathrm{Mu}-$ ranowie, i wreszcie mała Dotty - wnuczka polskiego emigranta, który wyjechał z kraju w latach osiemdziesiątych XX wieku. Wszystkie dziewczynki kochają swoją mirabelkę, przykładają ucho do jej pnia, nasłuchując wieści z dalekiego świata, wszystkie lubią kolorowe koraliki i złociste, słodkie owoce, które rodzi drzewko. Łączą je też wspólne korzenie i pamięć czy raczej postpamięć minionej kultury, jej obrzędów, obyczajów i straszliwego kresu. Dorastająca przed wojną Dorka wyszła za mąż za Chaima i urodziła synka Noamka, który ocalał z Zagłady, przemycony z getta na aryjską stronę. Jego matka, szalona z rozpaczy, $\mathrm{z}$ uśmiechem wsiadła do pociągu na Umschlagplatzu, rojąc o rychłym spotkaniu z synem. Dorotka - córka socjalistycznego przodownika pracy, który Stalina miał za łobuza - mieszka $\mathrm{w}$ domu zbudowanym $\mathrm{z}$ cegieł wydobytych $\mathrm{z}$ ruin spalonego miasta, bawi się wygrzebanymi z ziemi koralikami pozostałymi po właścicielach przedwojennej fabryczki strojów karnawałowych, a czasem czuje, że towarzyszą jej niewidzialni opiekunowie, którzy karcą jej kota i udzielają wsparcia w obliczu stalinowskich aresztowań. Ostatecznie dorosła już Dorota wiąże swoje życie z Maćkiem-Noamem, który wychował się w polskiej rodzinie, długo nieświadomy swej tożsamości. Oboje przetrwali represje w 1968 roku, ale emigrowali $\mathrm{w}$ czasie stanu wojennego, zabierając $\mathrm{z}$ sobą przypadkiem pestkę mirabelki. To właśnie pod drzewkiem wychodowanym z tej pestki w ogrodzie nieopodal Waszyngtonu, bawi się ich wnuczka Dotty, dorastająca w aurze miłości i nostalgii. Amerykańska mirabelka mówi:

Tęsknię. Tęsknię za mamą, babcią, prababcią, chociaż ich właściwie nie znałam. Tęsknię za ziemią, z której wyrosły. Tęsknię za Nalewkami, za ulicą Świętojerską, Wałową, Franciszkańską, za ulicą generała Andersa. Bo to jest przecież ziemia mojej mamy, babci i prababci, to jest NASZA ziemia. Tak chciałabym tam wrócić, choćby tylko częściowo... O tych naszych ulicach opowiadał mi mój Wojtuś, który wiele się dowiedział od swojej mamy i swojego taty.

Harasimowicz, 2018, s. 194

O poczuciu tożsamości decyduje więc pamięć organicznie wpisana w geny, dziedziczona po matce i babce, ale też zapośredniczona, przekazywana w opowieści przez Maćka-Noama i jego syna Wojtka. Z wolna odchodzą ostatni świadkowie tamtych wydarzeń, a miejsce wspomnień zajmuje postpamięć, budowana na podstawie cudzych narracji, niejednokrotnie zachowanych w tekstach kultury (Leociak, 2011). Mirabelka wyposaża młodych czytelników w postpamięć wyjątkowo silną, bo zapośredniczoną nie przez indywidualne wspomnienia, lecz przez wyobraźnię i twórczość (Hirsch, 2010, s. 254).

Tytułowe drzewko zna radości i kłopoty wszystkich sąsiadów, dzięki rozbudowanym systemom korzeniowym i zapachom innych drzew wie, co dzieje się w całej Warszawie, a po wojnie wyczuwa obecność dawnych mieszkańców Nalewek, którzy powracają do swoich siedzib i powierzają mirabelce najwięk- 
sze troski. Widma nawiedzające współczesny świat dostrzegają nieliczni. Niewielu słyszy też głos zdziczałego drzewka - świadka minionych wydarzeń. Wrażliwość na tego rodzaju spektrum wykazują dzieci, kobiety, może artyści jednostki wykluczone $\mathrm{z}$ oficjalnego dyskursu i zdecydowanie pozostające poza kręgiem władzy. Możliwość palimpsestowego czytania miasta, dialogu z jego podskórnym krwiobiegiem, odczytania głosów płynących z zaświatów - komunikatów przekazywanych przez drzewa czy obrazów dawnej Warszawy przebijających spod zmienionego pejzażu - zostaje dana bohaterom pozostającym poza głównym nurtem wydarzeń, patrzącym z eks-centrycznej (Borkowska, 1991, s. 45) perspektywy, naruszającym odgórnie ustalony porządek świata (Kraskowska, 2010, s. 23).

Dziewczynka, która widzi, że ktoś przygląda się jej kotu; niepełnosprawny intelektualnie Romek, przeczuwający istnienie podziemnego miasta; skrzypaczka w tajemniczy sposób obdarowana doskonałym instrumentem - wszyscy oni ustanawiają swą tożsamość w relacji do Innego, subiektywnie postrzegając i przekształcając rzeczywistość (Momro, 2014, s. 16). Dzięki temu w społeczność powojennej Warszawy wpisują się przeszłe istnienia, powracające jako widma lub przywoływane we wspomnieniach współczesnych, którzy muszą pamiętać o przeszłości, jeśli chcą odnaleźć swoje miejsce w życiu. Istnieją bowiem w ciągu historycznych wydarzeń, stanowią element łańcucha okrutnych przemian, nolens volens, stają się dziedzicami tego, co pozostawili po sobie dawni mieszkańcy Nalewek. „To nie są duchy, tylko dawni mieszkańcy tej ulicy” — wyjaśnia mirabelka Romkowi tajemnicze współistnienie przeszłości i dnia dzisiejszego. Zaniepokojeni przychodzą do swych dawnych domów, warsztatów i sklepów, aby po chwili znów wrócić do siebie, pod ziemię, bo - jak mówi chłopak - „tu jest drugie miasto pod spodem" (Harasimowicz, 2018, s. 161). Mirabelka wrasta więc w pamięć o tamtym mieście, szumiąc konarami w zbudowanej na gruzach Warszawie.

Miasto stanowi żywy organizm, ale na jego podmiotowość składa się przede wszystkim świadomość współczesnych mieszkańców, którzy dokonują swego rodzaju inkorporacji - w fantazmatyczny sposób, dzięki autoplastycznym zdolnościom, przeprowadzają substytucję utraconych fragmentów rzeczywistości, nie tylko cudzych istnień, ale przede wszystkim elementów kultury i przestrzeni powiązanej z urbanistyczną tkanką warszawskich ulic (Momro, 2014, s. 358). Jeśli zatem mieszkańcy miast zgodnie z teorią Kevina Lyncha (Lynch, 1960, s. 18-19) formują swoje mapy mentalne, opierając się na postrzeganych w przestrzeni formach materialnych, warszawiacy tkwią w tkance architektonicznej, która w konsekwencji dramatycznych wydarzeń historii XX wieku uległa radykalnym przekształceniom. Pamięć dawnych ulic, dzielnic przekazywana kolejnym pokoleniom pozostaje wpisana w obraz współczesnej Warszawy i oddziałuje na mieszkańców. Pozostając w sferze wspomnień wspólnych, należących do całej społeczności i dziedziczonych prawem postpamięci obraz obiektów niewidocznych, 
niematerialnych, niedostrzegalnych, widmowych, oddziałuje na przestrzenną widmobraźnię (Bukowiecki, 2016, s. 309) i determinuje palimpsestowy sposób czytania miasta, w którym nad jednym tekstem nadpisano kolejne narracje (Bukowiecki, 2016, s. 312).

Budowanie postpamięci jest możliwe dzięki oparciu się na lieux de memoire - miejscach pamięci dostępnych współczesnym pokoleniom, stanowiących uzupełnienie naturalnych środowisk pamięci (milieux de memoire) świadków i uczestników wydarzeń. Szczególnym sposobem upamiętnienia, szansą na zbudowanie pamięci protetycznej, są teksty kultury, wyprowadzające widma z przestrzeni nieświadomości do rejestru świadomie budowanej opowieści, poszukującej prawdziwej tożsamości miejsca w szczególny sposób dotkniętego przez historię (Szpociński, 2008, s. 11-12). Archeologia pamięci jest możliwa, jeśli za symbolicznymi gestami upamiętnienia stoi konkretna wiedza na temat przeszłości (Wójcik-Dudek, 2016, s. 251).

Nośnikiem pamięci w Mirabelce są przestrzeń oraz zakorzenione w niej owocowe drzewko. Ścięcie tytułowej mirabelki jest więc zbrodnią przeciw pamięci, szczególną powtórką Zagłady, na którą nie można pozwolić. Protest przeciw odcięciu od korzeni ma miejsce w tekstowej i pozatekstowej rzeczywistości. Pobieranie szczepek z amerykańskiej mirabelki i hodowanie sadzonek, które ostatecznie zadomowią się na Muranowie, realizuje nie tylko powieściowa Dorota, ale także kilka osób związanych ze Stowarzyszeniem „Grupa Muranów”. Mieszkańcy Warszawy zareagowali na zniszczenie mirabelki opisanej w reportażach Hanny Krall (Krall, 1998) - wytrwale zabiegali o posadzenie nowych drzewek i zachowanie pamięci (Bielaszyn, 2018).

Żyjemy w świecie nawiedzonym, a nasza współczesność podszyta jest wspomnieniem Zagłady. Świadomość minionych zbrodni w niewielkim stopniu przyczyniła się jednak do poprawy morale ludzkości. Odrzucanie wniosków dotyczących destrukcyjnego charakteru nienawiści i zgubny brak otwartości na Innego sprawiają, że Zagłada nie straciła aktualnego wymiaru i jak każda trauma, wciąż należy do teraźniejszości. Można zatem za Zygmuntem Baumanem powiedzieć, że „widmo Holokaustu krąży dziś po świecie, a świat nękany przez widmo jest nawiedzonym światem" (Bauman, 2009, s. 15). W tym kontekście Muranów staje się szczególnym tekstem kultury, który wymaga pogłębionej interpretacji przestrzenią nie śmierci, lecz życia, które nie powinno odejść w niepamięć; równocześnie kryptą i skryptem transfenomenologicznym (Derrida, 2016, s. 167). Słowo wymaga deszyfracji, skrywają się pod nim dodatkowe sensy, stanowi - jak pisze Jakub Momro - archeonim, „partykularny, fragmentaryczny odprysk pełnego języka komunikacji” (Momro, 2014, s. 357). Widma funkcjonujące w dynamicznie zmieniającym się języku marzenia sennego stanowią znaki odsyłające do kolejnych warstw historii i do przeszłości miejsca, w którym zaistniały - należą do współczesnego miasta, ale stanowią również ślad dawnej Warszawy, żydowskiej społeczności i kultury, która bezpowrotnie odeszła w przeszłość. 
Sylwia Karolak pisze:

Nie wystarczy powiedzieć, że tej zbiorowości już w polskim krajobrazie nie ma. To na terenach dzisiejszej Polski naziści dokonali mordu rasowego na niewyobrażalną skalę, pozbawiając życia blisko 4 miliony europejskich, w tym 98\% polskich Żydów. Tutaj założono, a następnie „zlikwidowano” getta, tutaj polowano na uciekających z transportów, na ukrywających się po „aryjskiej stronie".

Karolak, 2013, s. 118

Interpretacja przestrzeni wielu polskich miast jest nie tylko sposobem budowania pamięci protetycznej, ale sprzyja też oswojeniu widm, które - objęte symbolicznym rytuałem - przestają przerażać, a zaczynają współistnieć z rzeczywistością. Pamięć o rzeczach straszliwych ma wymiar pozytywny, spychanie ich do niepamięci jest równoznaczne z destrukcją, która nie dotyka przeszłości, ale niszczy sam podmiot, odcinając go od korzeni i pozbawiając samoświadomości. Duchy zamordowanych Żydów pojawiające się na warszawskich ulicach to echo historii usuniętej z oficjalnego obiegu, zepchniętej do społecznej nieświadomości. Widmo może być śladem wyparcia i negacji, projekcją pozostałą w pamięci, znakiem, który rozbija freudowską psychoanalityczną ekonomię (Momro, 2014, s. 152). Jego istota polega na niepokojącej zjawiskowości czegoś niematerialnego, co „tymczasowo zyskuje zauważalne kształty, niespodziewanie wyłania się z mrocznych zaświatów i znika, powracając w rytmie kolejnych nawiedzeń" (Grochowski, 2016, s. 4). Widmo pozostaje zawieszone między bytem a niebytem. Nie jest jednak duchem, którego należałoby się bać, nie budzi grozy, lecz szczególny rodzaj uśmiechu (Bielik-Robson, 2016, s. 37). Zgładzeni powracają nie po to, aby szkodzić żywym. Dorka i Chaim nawet po śmierci szukają swojego zagubionego synka, towarzyszą im dziadkowie i przyjaciele. Stawką tych poszukiwań jest coś więcej niż ukojenie tęsknoty i rozpaczy — chodzi o tożsamość żydowskiego chłopca, który - ocalony przez Irenę Sendlerową - dorastał jako Maciek, wychowany przez polską rodzinę. To on, cudem odnaleziony, stanie się strażnikiem pamięci, na nowo wrośnie w swe korzenie i choć ostatecznie wyemigruje znękany polską rzeczywistością, przekaże swoją wiedzę następnym pokoleniom.

Widma, które nawiedzają warszawskie podwórko, mają po części audialny charakter. Muzyka łączy teraźniejszość z przeszłością, opływa całą dzielnicę, niesie radość jak kolorowe koraliki braci Alfusów, a widmo skrzypiec pana Izaaka konkretyzuje się we współczesnym świecie. W tym przypadku widmontologia wykracza poza paradygmat wizualności i opiera się na modelu dźwiękowym (Momro, 2016, s. 38), bo muzyka oddziela się od instrumentu, istnieje niezależnie, towarzysząc skrzypkowi w pozazmysłowym świecie. Drogocenny Amati ze sfery widm znów wraca do żywych, aby służyć Dorocie - utalentowanej skrzy- 
paczce, która emigrując, nie mogła wywieźć z Polski swoich skrzypiec. Widmo pana Izaaka, skrzypka z Nalewek, pomaga jej doskonalić umiejętności, opiekuje się jej rodziną, dziećmi ze swojego podwórka, ludźmi spacerującymi po ulicach i nawet jeśli oni nie zdają sobie z tego sprawy, zmieniają się i zmienia się ich życie. Widma funkcjonują w wirtualnym czwartym wymiarze, a kierowane ku nim spojrzenie staje się - co podkreślał Jakub Momro - jakby tautologiczne i w pewien sposób ślepe. Żydzi przechadzający się po warszawskich powojennych ulicach są widziani i niewidziani równocześnie. Ich niewątpliwa obecność i równoczesna niewidzialność sprawiają, że kierowane ku nim spojrzenia powracają do obserwatora przemienione w spojrzenie Innego, jak gdyby omiatając otaczającą rzeczywistość, odbijały się w tajemniczym zwierciadle, w lustrze weneckim, cienką warstwą oddzielającym świat realny od sfery metafizycznej (Momro, 2014, s. 13).

Dorka, Chaim, Joszua, Rebeka, Halina, Jan, Izaak, bracia Alfusowie należą nie tylko do przestrzeni Warszawy. Pamięć o nich pozostaje wpisana w krwiobieg, przenika do soków tej ziemi, aby wraz z ocalałym Maćkiem i pestką mirabelki żyć nawet na obczyźnie. W pewnym sensie Mirabelka staje się więc poszukiwaniem sposobu, który pozwoliłby oswoić demony przeszłości. Cezary Harasimowicz proponuje rytuał, który pomógłby włączyć świadomość Zagłady i pamięć o zamordowanych do porządku symbolicznego, a towarzyszący nawiedzeniom niepokój pozwolił przemienić w moralny impuls chroniący przed nienawiścią i budujący poczucie ponadkulturowej wspólnoty. W powieści silnie podkreślone zostały powinowactwa łączące rodziny z rozmaitych kręgów kulturowych, ludzi żyjących w różnych epokach i przestrzeniach, dzieci wyciągające ręce po złociste mirabelki. Miłość i dziecięca niewinność połączone z brakiem uprzedzeń powtarzają się w kolejnych pokoleniach pojawiających się na kartach książki, a powracający obraz dziecka spędzającego czas pod owocowym drzewem przywołuje na myśl spędzane w ogrodzie rajskim dziecięctwo rodzaju ludzkiego. Kolejne Dorotki bawiące się nieopodal mirabelki to dowód na wielką moc miłości i siłę życia, które wciąż się odradza, obudowując straszliwą przeszłość i czyniąc z niej element wspólnej tożsamości. Zagłada wpisana jest w ziemię, na której się dokonała. Symboliczne zasadzenie mirabelek, które następuje w finale powieści, staje się rytualnym wyrazem pamięci i próbą zapewnienia spokoju widmom błąkającym się po posttraumatycznym świecie. Mimo niemożliwej do przepracowania żałoby powiązanej z przypadkami śmierci niewyobrażalnymi i skrajnie transgresywnymi w Mirabelce zbudowany zostaje most porozumienia między umarłymi i żywymi. Widma powracające na warszawskie ulice są przyjazne, nie budzą lęku, pomagają głównym bohaterom w trudnych sytuacjach, zdecydowanie stają po stronie dobra, wolności jednostki, przeciw systemowej opresji. Międzyludzka solidarność - przekraczająca różnice kulturowe, religijne, barierę czasu i śmierci - pozwala wyciągnąć wnioski z lekcji historii, hartuje przeciw konformizmowi, pomaga przeciwstawiać się temu, co niesłusz- 
ne. Kapłanką ponadczasowych więzi jest mirabelka, rodząca słodkie, nasycone miłością i słońcem owoce.

Zwierzęta i rośliny w utworach dla dzieci często ulegają antropomorfizacji, która jednak nie tylko czyni je podobnymi do człowieka, ale umożliwia też przemawianie własnym głosem i konstruowanie alternatywnej perspektywy. Literatura staje więc „miejscem możliwego spotkania $\mathrm{z}$ innym, pozaludzkim punktem widzenia" (Mytych-Forajter, 2020, s. 28) oraz przestrzenią międzygatunkowych dialogów. Mirabelka, którą czytelnik poznaje na pierwszych stronach książki Harasimowicza, jest młodym drzewkiem, rośnie na warszawskim podwórku tuż obok swej matki. Jako dziecko-drzewo wydaje się podwójnie zagrożona wykluczeniem i pozbawieniem prawa głosu. W swym dziecięctwie, dojrzewaniu, owocowaniu, starości jest paralelna wobec ludzkich bohaterek powieści. Nie staje się jednak bohaterką subdziecięcą, spoglądającą na świat oczami najmłodszych. Pozostaje drzewem, osią świata, znakiem arbor vitae z ogrodu rajskiego, o gałęziach obsypanych złocistymi owocami.

Jej owoce są drobne jak koraliki braci Alfusów, swoją słodyczą niosą pociechę, gaszą pragnienie i głód. Z pestek kiełkują nowe rośliny, mocno wrastając w gliniastą, nieurodzajną glebę. Mieszkańcy pobliskich kamienic starannie zbierają jej owoce, szanując drzewo i jego dary. Nie marnują jedzenia nie tylko z biedy czy oszczędności, kierują się też szacunkiem dla wszystkiego, co rośnie, rozkwita, owocuje i przynosi pożytek. To drobne żółte śliweczki są prawdziwym skarbem tej ziemi, nie złoto zakopane pod korzeniami mirabelki, które nikogo nie uratuje, przyniesie tylko zgubę, rozpacz i śmierć. Ocalą nas mirabelki wrośnięte w nieurodzajny grunt drzewa, przechowujące w swych owocach przywiązanie do rodzinnej ziemi, jabłonie kryjące wśród korzeni informacje o prawdziwej tożsamości żydowskich dzieci ocalonych przez Irenę Sendlerową, lipy i kasztany przekazujące przydatne informacje. Jeśli w kulturze judejskiej każdy ogród jest odbiciem i powieleniem Edenu, tu został on rozproszony po świecie. Drzewa rozsiane między ludźmi dają im chwilę pociechy i wytchnienia, niosą w sobie okruch rajskiego ogrodu, przywracają pierwotną niewinność i poczucie harmonii ze światem. To dlatego mogą rozmawiać z dziećmi - istotami nieskażonymi jeszcze żadnym występkiem, ze swej natury należącymi do rajskiego porządku. Towarzyszą ludziom w ich ziemskiej wędrówce, ale stają się też strażnikami, opiekunami, przypominają o właściwej skali wartości. Komunikacja z mirabelką to kontakt ze światem przyrody, ale i możliwość dotarcia do podszewki świata, do jego metafizycznego zaplecza. Rozpatrywanie roli mirabelki w perspektywie ekokrytycznej pozwala w powieści Harasimowicza ujrzeć wyraz tęsknoty za dawną harmonią człowieka $\mathrm{z}$ naturą. Relacja ta - związek pierwotny i prymarny - pozwala też odczuć porządek ukryty i naddany, wpisany w świat przyrody. Umiłowanie natury i metafizyczna wrażliwość łączą się z sobą w nierozerwalny konglomerat. 
Mirabelka - narratorka i protagonistka powieści Harasimowicza - pozostaje zakorzeniona $\mathrm{w}$ jednym miejscu, nie porusza się, nie przemyka po ulicach Warszawy, tkwi wciąż na tym samym podwórku, obserwując mieszkańców kilku kamienic. Wpisana w matriarchalny porządek, dziedzicząca cechy po swej matce i babce, związana z nimi systemem korzeni, czerpie z teraźniejszości i przeszłości, a kolejnym dziewczynkom przykładającym ucho do pnia opowiada niezwykłe historie. Czytelnik równocześnie poznaje więc opowieść mirabelki i opowieść o mirabelce - drzewie, które stało się pomnikiem pamięci (Gralewicz-Wolny, 2020, s. 11, 17)1. Małgorzata Wójcik-Dudek tak pisze o monumentach upamiętniających heroizm Janusza Korczaka:

[...] pomniki stają się punktami orientacyjnymi na planie miasta, które w jakimś sensie należy także do Korczaka i jego dzieci. Mapowanie Korczakowskich miejsc stanowi próbę osadzenia narracji przeszłości we współczesnej pamięci metropolii.

Wójcik-Dudek, 2016, s. 104

Zamordowani w czasie wojny bohaterowie Mirabelki nie mogą liczyć na pamiątkowe tablice, monumenty czy obeliski. To przeciętni przedstawiciele zróżnicowanej żydowskiej społeczności - handlarze, rzemieślnicy, drobni przedsiębiorcy, urzędnicy bankowi, kobiety pełniące przypisane im społecznie role, gromadka dzieci. Ich pomnikiem jest właśnie mirabelka, która - podobnie jak drzewo wkomponowane $\mathrm{w}$ jeden $\mathrm{z}$ pomników Korczaka - „stanowi nie tylko axis mundi świata, którego już nie ma, lecz także centrum tego, który nadal trwa" (Wójcik-Dudek, 2016, s. 104)2.

Mirabelka upomina się o pamięć, lecz oszczędza dziecięcemu odbiorcy straszliwych szczegółów, opisów historycznych zbrodni i obrazów ludobójstwa. Pomaga zadawać pytania, podpowiada, gdzie szukać wiadomości na temat Zagłady, ale nie przynosi jednoznacznych odpowiedzi. Zapewne sama ich nie zna - jest tylko młodym drzewkiem rosnącym na warszawskim podwórku, wie tyle, ile opowiedziała jej mama, podszepnął zapach kasztanów z ogrodu Krasińskich czy woń lip kwitnących intensywnie w lipcu 1942 roku, gdy rozpoczęto likwidację warszawskiego getta. Takie ukształtowanie narracji jest charakterystyczne dla dziecięcego sposobu widzenia świata, którego obraz tworzony na podstawie dostępnych informacji pozostaje pełen luk i domysłów. Pozwala też uniknąć epato-

\footnotetext{
${ }^{1}$ Iwona Gralewicz-Wolny, analizując $O$ czym szumiq wierzby, wskazuje niezwykłe znaczenie rzeki, zaznaczając podwójny wymiar tej lektury („słuchamy jednocześnie opowieści o rzece i opowieści rzeki”). Można powiedzieć, że podobną funkcję — partnerowania pozostałym bohaterom w książce Harasimowicza pełni właśnie tytułowa mirabelka, nie tak świadoma, jak Rzeka z opowieści Grahame’a, ale równie mocno związana ze „swoimi ludźmi” (Gralewicz-Wolny, 2020, s. 9-18).

${ }^{2}$ Pomnik Janusza Korczaka według projektu Zbigniewa Wilmy przedstawia gromadę dzieci otaczającą wybitnego pedagoga, stojących pod uschniętym drzewem, którego konary przypominają ośmioramienną menorę (Wójcik-Dudek, 2016, s. 104).
} 
wania okrucieństwem i faktograficznej relacji o zbrodni, koncentrując się wokół przejmującej opowieści o przemijaniu i kulturze, która już nie wróci.

Magiczne drzewo o złotych owocach ma też charakter baśniowy. Gadające wierzby, spróchniałe pnie kryjące skarby czy umożliwiające pasaż do innego świata to stałe elementy baśniowego sztafażu (Wójcik-Dudek, 2016, s. 158 i nast.). Wydawać by się mogło, że straszliwe wydarzenia wojenne wpisane w tę konwencję zostaną pozbawione grozy, a staną się częścią uniwersalnego porządku przemijania i wiecznych odrodzeń. Baśniowy charakter opowieści złamany jednak zostaje trudnym i nie w pełni optymistycznym zakończeniem. Przemijaniu i zagładzie bowiem to ulega, co wydawało się wiecznotrwałe. Pod ciosami siekiery ginie mirabelka, a wraz z nią — jak się zdaje - umiera historia, której nikt już nie będzie śledził ani opowiadał. Owocujące złotymi kulkami drzewo znika z powierzchni ziemi, jak zniknęli wcześniej bohaterowie jej opowieści. Zasadą świata jest przemijanie, kolejni bohaterowie opowieści odchodzą w niepamięć, ale na kartach historii pojawiają się nowi, którzy w pewnym sensie powtarzają dawne biografie - kochają, zakładają rodziny, budują międzyludzkie relacje. Życie trwa z niesłabnącą mocą, miłość łączy kolejne pary, a małe dziewczynki wciąż przytulają się do pnia mirabelki, aby usłyszeć głosy przeszłości budujące współczesną historię. Aby to było możliwe, potrzebny jest jednak świadomy, ludzki gest przywracający pamięć - ręka, która posadzi mirabelkę, nada jej znaczenie i da schronienie widmom pragnącym odwiedzić swój dawny dom.

\section{Literatura}

Bauman Z., 2009, Świat nawiedzony, w: Czapliński P., Domańska E., Zagłada. Wspótczesne problemy rozumienia i przedstawienia, Poznań 2009, s. 7-34. Esej, wcześniej opublikowany na łamach „Więzi” 2007, nr 8-9. http://wiez.com.pl/2020/02/28/ swiat-nawiedzony/ [data dostępu: 15.04.2020].

Bieliaszyn W., 2018, Stynna mirabelka z Nalewek wróciła na Muranów. Drzewko przyleciało ze Stanów Zjednoczonych, „Gazeta Wyborcza” z 20 września 2018. https://war szawa.wyborcza.pl/warszawa/7,54420,23955201,slynna-mirabelka-wrocila-na-mura now-drzewko-przylecialo-ze.html [data dostępu: 15.04.2020].

Bielik-Robson A., 2016, Uśmiech widma bez Ciała: kabalistyczna baśń z Derrida w tle, „Teksty Drugie”, nr 2, s. 15-37.

Borkowska G., 1991, Szymborska eks-centryczna, „Teksty Drugie”, nr 4, s. 45-58.

Bukowiecki Ł., 2016, „Tu było skrzyżowanie...”. O widmobraźni przestrzennej w Warszawie, „Teksty Drugie”, nr 2, s. 309-323.

Derrida J., 2016, Fora. „Kanciaste” słowa Nicolasa Abrahama i Márii Török, Brzezicka B., przeł., „Teksty Drugie”, nr 2, s. 122-168.

Gralewicz-Wolny I., 2020, „Gdzieś nieopodal płynie rzeka”. O czym szumia wierzby Kennetha Grahame'a, w: Gralewicz-Wolny I., Mytych-Forajter B., Po pierwsze. O literaturze dla dzieci (i nie tylko), Kraków, s. 9-18. 
Grochowski G., 2016, Nawiedzony numer, „Teksty Drugie”, nr 2, s. 7-13.

Harasimowicz C., 2018, Mirabelka, Warszawa.

Hirsch M., 2010, Żałoba i postpamięć, Bojarska K., przeł., w: Domańska E., red., Teoria wiedzy o przeszłości na tle wspótczesnej humanistyki. Antologia, Poznań, s. 247-280.

Karolak S., 2013, Widma (z) Zagłady, „Czas Kultury”, nr 2, s. 118-125.

Krall H., 1998, Obecność, w: tejże, Tam już nie ma żadnej rzeki, Kraków, s. 126-134.

Kraskowska E., 2010, Czytelnik jako kobieta, Poznań.

Leociak J., 2011, Koniec ery pamięci, „Tygodnik Powszechny”, nr 50. https://www.tygo dnikpowszechny.pl/koniec-ery-pamieci-141098 [data dostępu: 20.04.2020].

Lynch K., 1960, The Image of the City, Cambridge.

Marzec A., 2015, Widmontologia. Teoria filozoficzna i praktyka artystyczna ponowoczesności, Poznań.

Momro J., 2014, Widmontologie nowoczesności. Genezy, Warszawa.

Momro J., 2016, Echo i medium, „Teksty Drugie”, nr 2, s. 38-54.

Mytych-Forajter B., 2020, „Doktor Dolittle i jego zwierzęta” Hugha Loftinga - lektura ekokrytyczna, w: Gralewicz-Wolny I., Mytych-Forajter B., Po pierwsze. O literaturze dla dzieci ( $i$ nie tylko), Kraków, s. 19-30.

Szpociński A., 2008, „Miejsca pamięci (milieux de memoire)”, „Teksty Drugie”, nr 4, s. $11-20$.

Wójcik-Dudek M., 2016, W(y)czytać zagładę. Praktyki postpamięci w polskiej literaturze XXI wieku dla dzieci i młodzieży, Katowice.

Agnieszka Kwiatkowska - dr hab. prof. UAM w Zakładzie Literatury XX wieku, Teorii Literatury i Sztuki Przekładu na Uniwersytecie im. Adama Mickiewicza w Poznaniu, badaczka literatury XX-wiecznej, szczególnie poezji awangardowej i twórczości dla dzieci. Autorka prac poświęconych liryce Juliana Przybosia oraz studiów dotyczących poezji dla dzieci pisanej przez kobiety (m.in. Danutę Wawiłow, Annę Podczaszy, Joannę Mueller).

e-mail: agak@amu.edu.pl 